\title{
THE PAKISTAN MOVEMENT AND FEDERALISM
}

\author{
Saeed Ahmed Rid \\ Assistant Professor, National Institute of Pakistan Studies, \\ Quaid-i-Azam University, Islamabad \\ saeedrid@qau.edu.pk
}

\begin{abstract}
The careful reading of the history of Pakistan movement tells us the movement rose in response to the fear of the imposition of majoritarian- unitary democracy model in British India following the West Minister model. After 1857 war of independence, Sir Sayed Ahmed Khan had advised Muslims not to take part in politics and focus their energies on acquiring modern education and hence securing their due share in bureaucratic positions under the British rule. But when Congress was formed in 1885 and gradually democratic reforms were introduced, the fear of majoritarian-unitary model started creeping in among the Muslim elite. The leaders of Muslim League felt if the Westminster style majoritarian- unitary democracy model is introduced in British India that will ultimately bring over the centralized Congress rule in British India which they equated as the Hindu raj. The debate around the federal question remained on top of the agenda in British India since the announcement of the Nehru report in 1928. The failure of the Congress in addressing Muslim concerns regarding majoritarian- unitary democracy model ultimately led to the partition of India in 1947. In this paper the debate around the federal question and the demands for consociational democracy in Pakistan movement would be studied in detail and it will be analysed how far the failure of addressing the federal question was responsible for the partition of India.
\end{abstract}

Keywords: Majoritarian Democracy, Indo-Pak History, Consociationalism, All India Muslim League, Muslim Separatism

\section{INTRODUCTION}

Britain, the colonial masters of India, despite having a unitary system of government in their homeland, decided to introduce the federal system in British India under the Montagu-Chelmsford reforms of 1919 and then strengthened it in the Government of India Act 1935. It is interesting that since 1919 reforms, federalism was never in question in united India before partition and later in both India and Pakistan after the independence. However, the quantum of provincial autonomy and the power-sharing mechanism between the federation and its units has always remained under serious political debate and contestation in both countries.

The scholarship available on Pakistan movement has mostly delt it as a subject of history more than that of the politics. Therefore, in most of the academic literature available on topic more emphasis is given to the major developments and details of the events starting from the war of independence 1857 to the events that led to the partition in 1947. In the United Kingdom authors like Coupland (1944), Campbell-Johnson (1952), Rawlinson (1948), Smith (1958) and many others saw it more in the context of the historical studies on British Raj in India. In India, the Pakistan movement is either ignored or some authors like Gandhi (1949), Menon (1957), Gopal (1959) and Azad (1959) discussed it as an irritant and a communal problem in the struggle for freedom of India from the colonial British rule. Similarly, in Pakistan Khaliquzzaman (1961), Malik (1963), Waheed-uz-Zaman (1964), Ikram (1965), Qureshi (1965), Ali (1967), Sayeed (1968) and many others kept the focus on historical discussion of the events starting from the war of independence 1857 that led to the HinduMuslim conflict and finally the partition of India in 1947.

The political and constitutional developments from 1858-1947 are discussed in great detail in all that literature produced in Pakistan, India and the United Kingdom during that early phase and even later on, but the theories of political science like federalism, democracy, majoritarianism and consociational democracy have seldom been used as a lens to make sense of those political developments. Among political science theories nationalism, right of self-determination, colonialism, imperialism, and decolonization have remained the over-riding themes for that phase in most of the 
studies. Hence, this would be a pioneering work applying the federalism and consociational democracy lens to study the Pakistan movement.

The Pakistan movement is mostly explained in terms of one-nation theory versus two-nation theory and competing nationalist ideologies of Indian nationalism and Muslim nationalism upheld by the Congress and Muslim League respectively. No doubt this was an important lens to look at the developments of twentieth century because there was an upsurge of the rise of nationalist movements across the world in that phase. But surely it was not the only lens through which the demand for Pakistan can be looked at.

The theory of nationalism does help explaining the Pakistan movement as it is aptly used by K.K. Aziz in his seminal work, The Making of Pakistan: A Study in Nationalism, originally published in 1967. But it does not help us decipher the realpolitik and the power-sharing disputes between Hindus and Muslim which in my understanding were more instrumental behind the partition of India in 1947. The sequence of events starting from late $19^{\text {th }}$ century tells us the Hindu-Muslim conflict in British India evolved with the process of democratization in colonial India. The fear of majoritarian Westminster model of democracy started creeping in the minds of the Muslim leadership as soon as democratic reforms were introduced in British India. Muslims felt in the Westminster model of democracy, Hindus will always dominate the power politics in India as Muslim with a permanent minority status will have very little say in the affairs of the state specially in centre.

The Muslim leadership of all shades of opinions not just the Muslim League, from late 1920s started seeing federalism and maximum provincial autonomy as the only solace they could get under democratic India. Therefore, federalism became a recurrent theme of the Muslim discourse in 1930s up to the time of partition in 1947. This paper is an attempt to focus on the federalism discourse in Pakistan movement and study how it explains and informs our understanding of the Pakistan movement.

\section{Research Question}

The main research question of this research paper is to study the centrality of the federalism discourse and the demands for consociational democracy in Pakistan movement and analyse how far the failure of addressing the federal question was responsible for the partition of India in 1947 ?

\section{RESEARCH METHODOLOGY}

This is primarily a qualitative research to provide in-depth historical analysis of the Pakistan movement and its connection with the ideas of federalism, majoritarian Westminster model of democracy and consociational democracy in colonial India. This is a desk research where all possible primary and secondary sources are used to collect the relevant data on the topic. There is abundant secondary data available on the topic in the form national archives, speeches, books, research journals, newspapers archives, and official documents, therefore, primary data like interviews etc. are not required.

\section{THEORY}

As mentioned above the theories of federalism, majoritarian Westminster model of democracy and consociational democracy are used as a lens to study the Pakistan movement. Federalism is understood here, as what William H. Riker defines it, "Federalism is a political organization in which the activities of government are divided between regional government and a central government in such a way that each kind of government has some activities on which it makes final decisions" (Riker, 1964, p.101). Hence, a federal state must have two sets of governments and each set enjoys autonomy in certain matters while leaving some decisions to the other set. The spirit of federalism lies in maximum provincial autonomy where only those subjects are left with the federal (central) government which are essential for the maintaining of the day-to-day affairs of the country and leaving all residuary powers to the provincial or regional governments.

The British Westminster model of democracy is termed as the majoritarian model by Arend Lijphart in his seminal work Patterns of Democracy originally published in 1999. In this study Lijphart's conceptions of majoritarian and consensus model (consociational) of democracy are used to understand and analyse the Pakistan movement. Lijphart has formulated ten dichotomous contrasts between the majoritarian and consensus models which clarify the two concepts of democracy very 
well. He divides the first five differences on the executives-parties dimension of the majoritarian model (listed first) and the consensus model as under:

1. Concentration of executive power in single-party majority cabinets versus executive powersharing in broad multiparty coalitions.

2. Executive-legislative relationships in which the executive is dominant versus executivelegislative balance of power.

3. Two-party versus multiparty systems.

4. Majoritarian and disproportional electoral systems versus proportional representation.

5. Pluralist interest group systems with free-for-all competition among groups versus coordinated and "corporatist" interest group systems aimed at compromise and concertation.

The other five differences on the federal-unitary dimension are:

1. Unitary and centralized government versus federal and decentralized government.

2. Concentration of legislative power in a unicameral legislature versus division of legislative power between two equally strong but differently constituted houses.

3. Flexible constitutions that can be amended by simple majorities versus rigid constitutions that can be changed only by extraordinary majorities.

4. Systems in which legislatures have the final word on the constitutionality of their own legislation versus systems in which laws are subject to a judicial review of their constitutionality by supreme or constitutional courts.

5. Central banks that are dependent on the executive versus independent central banks. (Lijphart, 2012, p.3-4)

\section{MAJORITARIAN DEMOCRACY AND THE PAKISTAN MOVEMENT}

The fear that Muslims rights would be unprotected in united India if Westminster style majoritarian democracy was introduced started creeping in the Muslim minds in later part of the $19^{\text {th }}$ century and became more and more evident with time. The legislative councils were introduced in British India under Indian Councils Act 1861 in which Indians were a minority as most of the members were either Europeans or Anglo-Indians. But with increased strength of Indian members in the legislative councils under Indian Councils Act 1892, the signs of increasing democratization process became obvious for the man of the stature of Sir Sayed Ahmed Khan who could easily see where it was leading to. Sir Sayed openly opposed the introduction of the parliamentary institutions in British India understanding Muslim's minority status with ratio of four to one against Hindus in democratic terms would put them at great disadvantage. In one of his speech in Lucknow, on 18th December 1887, Sir Sayed Ahmed Khan said,

The second demand of the National Congress is that the people should elect a section of the Viceroy's Council. They want to copy the English House of Lords and the House of Commons. The elected members are to be like members of the House of Commons; the appointed members like the House of Lords. Now, let us suppose the Viceroy's Council [to be] made in this manner. And let us suppose first of all that we have universal suffrage, as in America, and that everybody, chamars and all, have votes. And first suppose that all the Mahomedan electors vote for a Mahomedan member, and all Hindu electors for a Hindu member; and now count how many votes the Mahomedan members have and how many the Hindu. It is certain the Hindu members will have four times as many, because their population is four times as numerous. Therefore, we can prove by mathematics that there will be four votes for the Hindu to everyone vote for the Mahomedan. And now how can the Mahomedan guard his interests? It would be like a game of dice in which one man had four dice, and the other only one. (Pandey, 1979, p.14).

Sir Sayed not only considered the majoritarian democracy disadvantageous for the Muslims of India but also, he argued it did not suit the heterogenous countries like India. He argued the majoritarian model of democracy only suits the homogenous countries like Britain and that it did not suit India because of its religious, ethnic and caste differences,

So long as differences of race, and creed, and the distinctions of caste form an important element in the socio-political life of India, and influence her inhabitants in matters connected with the administration and welfare of the country at large, the 
system of election pure and simple cannot safely be adopted. The larger community would totally override the interests of the smaller community, and the ignorant public would hold Government responsible for introducing measures which might make the differences of race and creed more violent than ever (Phillips, 1962, p.185).

The Muslim leadership started feeling the effects of majoritarian democracy by the start of the twentieth century as their share in municipal councils started declining considerably. Like in Bengal alone Muslim's share in the legislative council declined from fifty percent to thirteen percent between 1895 and 1906 (Shaikh, 2012, p.131). On the other hand, in British policy for India the democratic reforms and movement towards representative democracy became inevitable with the turn of the twentieth century. The fear of the majoritarian model was very evident in famous 1930 Allahabad address of Allama Mohammad Iqbal as well, which many in Pakistan believe was the first political speech where Pakistan was demanded in principle. Allama had said, "The principle of European (majoritarian) democracy cannot be applied to India without recognising the facts of communal groups. The Muslim demand for the creation of a Muslim India within India is, therefore, perfectly justified" (Sherwani, 1977, p.5).

Therefore, for preserving the Muslim political interests, Sir Sayed's policy of 'aloofness from politics' was shunned and the formation of Muslim's own political party was considered essential. With this new understanding, a delegation of around twenty Muslims under the leadership of Aga Khan met with Lord Minto at Simla on October 1, 1906. In this meeting which is more famous in history as the Simla deputation, Muslims demanded the separate electorates for Muslims in all levels of the government on the grounds in joint franchise Muslims were the biggest losers. They gave the example of United Provinces where they constituted fourteen percent of the population, they could not secure a single seat in the legislative assembly (Sayeed, 1968). Finally, Muslim League was formally launched on December 30, 1906 to look after the political rights and interests of the Muslims of India as one of its stated objectives along with improving the relations with colonial masters and other communities as the other two objectives.

From 1906 onwards the issue of separate electorates remained as a major bone of contention between the Muslim League and the Congress leadership until it was finally resolved in the favour of the separate electorates under the communal award of 1932. Apparently, Quaid-i-Azam Mohammad Ali Jinnah had succeeded in resolving the issue of separate electorates when he was able to convince the Congress to accept the separate electorates and the principle of weightage for Muslims in minority provinces under the Lucknow pact signed in 1916 in return Muslim League accepted the Congress demand of swaraj (home rule). This shows at that point in history the Muslim political leadership and the Muslim League had considered the separate electorates and the weightage for Muslims in minority provinces provided the sufficient safeguards for the protection of Muslim interests.

\section{Federalism and the Pakistan Movement}

The demand for Pakistan in British India and the birth of Pakistan in 1947 have its roots in the federal principle. Sayed Jaffar Ahmed writes, "the federal principle was inherent in the evolution of the movement that culminated in the creation of Pakistan" in 1947 as since 1920s Muslim League was persistently demanding maximum provincial autonomy within British India (Ahmed, 2015, p.105). Muslim League was scared by the idea of introduction of the unitary system and the majoritarian Westminster model of democracy in India. They feared such a model would mean a permanent centralised Congress rule over whole of India as Hindus were a permanent majority and Muslims a permanent minority, leaving nothing for the Muslims in general and the Muslim League in particular in such a centralised unitary scheme.

Regarding the federalism and maximum provincial autonomy emerging as one of the major demands of the Muslim League, the annual session of Muslim League held at Lahore in 1924 is of the utmost importance. In this session for the first time Muslim League adopted federalism as one of its 'fundamental principles' for the Swaraj and the constitutional scheme of India. In this session Muslim League passed one of the historic resolutions and the first point of that resolution read as under:

The existing Provinces of India Shall all be united under a common Government on a federal basis so that each Province shall have full and complete Provincial Autonomy, the functions of the central government being confined to such matters only as are of general and common concern (Pirzada, 1970, p.577). 
Moreover, in the same resolution 'minority veto' was also demanded which is now considered as one of the important elements of the consensus (consociational) model of democracy. The resolution read:

No bill or resolution or part thereof affecting any community, which question is to be determined by the members of that community in the elected body concerned, shall be passed in any legislature or in any other elected body, if three-fourths of the members of that community in that particular body oppose such bill or resolution or part thereof (Pirzada, 1970, p.578)

The famous Nehru Report which was published in 1928 proved a watershed as it completely undid what was agreed in the Lucknow pact and technically closed all the doors of cooperation between Hindus and Muslims. This report provided the basic features of the future constitution of India as demanded by the Congress. In this report not only the principles of separate electorates and weightage (both were part of the Lucknow pact) were summarily rejected but also it enshrined the majoritarian model with highly centralised federal structure - residuary powers belonging to the centre and not provinces and provinces enjoying very little fiscal, administrative and legislative autonomy. The condemnation of the Nehru report by the Muslim leadership of different political affiliations was so strong that The Times correspondent reported, "The solidity of Muslim feeling in the Assembly was not unexpected, but certainly disturbing to those trying to represent the Nehru report as a demand of a united India" (The Times, March 13, 1929).

The different factions of the Muslim leaders met under one umbrella, the All-India Muslim conference under the chairmanship of Aga Khan on January 1, 1929 and demanded "the only form of government suitable to Indian conditions was a federal system with complete autonomy and residuary powers vested in the constituent states" (Gwayer and Appadorai, 1957, p.244). Moreover, the weightage and separated electorates were also demanded along with the due share for Muslims in the central and provincial cabinets (Gwayer and Appadorai, 1957, p.245).

\section{Quaid-i-Azam's Fourteen Points and the idea of Consociational Federalism}

Similarly, on March 28, 1929, Quaid-i-Azam Mohammad Ali Jinnah in his famous fourteen points had provided a comprehensive constitutional mechanism for addressing the Muslim grievances against introduction of the majoritarian model of democracy in India which Congress had demanded through Nehru report. If Jinnah's fourteen points are analysed on the principles of consensus model, most of his demands fell under what is now known as 'consociational federalism' (Elazar, 1985). Like Quaid-i-Azam demanded one third representation for Muslims in the central legislature and all cabinets either central or provincial despite knowing Muslims in terms of numbers were much less than the one-third of India's total population then and in many provinces their number even did not reach the two digits. A demand for Muslim community's share in the cabinet despite being a minority has no place in winner take all majoritarian model.

Moreover, the eighth point among fourteen points is exactly what is now known as the 'minority veto' in consociational theory. The eighth point reads as, "No bill or resolution or any part thereof should be passed in any legislature or any elected body if three-fourths of the members of a community in that particular body opposed such a bill" (Khan 2001, p,16). Similarly, the fourteenth point pertains to the extra-ordinary rigidity of the constitution, "No change should be made in the constitution by the central legislature except with the concurrence of the states constituting the Indian federation" (Khan 2001, p,17). It is obvious from Jinnah's speeches and policies in that phase of the history that he saw 'consociational federalism' as only solution of the communal problem in united India.

The Muslim safeguards demanded in Quiad-i-Azam's fourteen points on the basis of consociational federalism gradually became a rallying point around which all Muslim political leaders started getting united. This unity of the thought process among Muslim leaders along consociational federalism and fourteen points became obvious during the proceedings of the three round table conferences. In Round Table Conferences, the Muslim leadership which included Aga Khan, Sir Mohammad Shafi, Maulana Mohammad Ali Jauhar and Quaid-i-Azam all unanimously demanded the federal form of government in India with maximum provincial autonomy. Sir Mohammad Shafi told the conference, "there is only one form of government, one basis for the future constitution of India, 
which alone will suit the circumstances of the case - and that is the federal system (Indian Round Table Conference (First Session), Proceedings (London 1931), p.55).

On the federal question, Muslim leadership was so much unified that Maulana Mohammad Ali Jauhar, despite his close affiliations with Congress and Gandhi two days before his death on January 1, 1931 wrote a letter to the Prime Minster of Great Britain in which he echoed the Jinnah's fourteen points:

The real problem before us is to give full power to Muslims in such provinces as those in which they are in a majority, whether small or large, and protection to them in such provinces as those in which they are in a minority...... The Muslims desire and this is the crux of their 14 points and not separate electorates - that there should be federal government so that the central unity Government with a permanent Hindu majority should not override them everywhere (As cited in Waheed-uz-Zaman, 1978, p.65-66).

\section{Allama Iqbal's 1930 Allahabad Address and the Federal Question}

Along with Quaid-i-Azam's fourteen points Allama Iqbal's Allahabad address is considered as one of the most important pillars of the Pakistan movement, therefore, reading this address with the lens of federalism is very important for this paper. The careful reading of Allama Iqbal's Allahabad address reveals he is echoing and reinforcing the concept of consociational federalism given by Quaid-i-Azam in his fourteen points with a philosophical clarity and strong arguments. In his address Allama Iqbal argued the solution of Indian national question lie not in declaring India 'one nation' because "various caste units and religious units in India have shown no inclination to sink their respective individualities in a larger whole." (Asif, 2020, p.13). Rather, he called for the acceptance of the realities of the caste units and the religious units and creations of "autonomous states based on the unity of language, race, history, religion and identity of economic interests, is the only possible way to secure a stable constitutional structure in India" (Shamloo, 1948, p.15).

In his speech Iqbal completely rejected the idea of a unitary state and foresaw a civil war in India if such a scheme was imposed by the British government or Congress. He described federalism a viable solution for the communal problem in India, "The Muslims demand federation because it is pre-eminently a solution of India's most difficult problem, i.e. the communal problem". Moreover, he wanted the maximum provincial autonomy for the federating units, "What is called 'residuary powers' must be left entirely to self-governing states, the Central Federal State exercising only those powers which are expressly vested in it by the free consent of Federal States" (Shamloo, 1948, p.18). Hence, Iqbal wanted the provinces of India to have the powers to decide what kind of powers they would want to delegate to the federal government at the centre. Based on all this he uttered those historic words because of which many in Pakistan describe Iqbal as the one who saw the "dream of Pakistan'. Allama Iqbal had said,

I would like to see the Punjab, the North-West Frontier Province, Sindh and Baluchistan amalgamated into a single state. Self-government within the British Empire, or without the British Empire, the formation of a consolidated North-West Indian Muslim state appears to me to be the final destiny of the Muslims, at least of North-West India" (Shamloo, 1948, p. 12).

The above words are commonly understood in Pakistan as if Allama Iqbal was proposing an independent state for the Muslims of India. However, reading the whole speech of Allama Iqbal in the context of the politics of 1930s makes it abundantly clear that the idea of an independent Muslim nation-state was not there in the Allahabad address. Waheed-uz-Zaman clarifies the word 'state' was not used "with the meaning of a sovereign independent state but as a component and constituent unit of India" (Waheed-uz-Zaman, 1978, p.132).

In his Allahabad address Allama Iqbal clearly wanted a federal state but he proposed redistribution of the Indian provinces to create what he called "single state" with clear Muslim majority before the implementation of the federal scheme. After calling for the formation of "consolidated North-West Indian Muslim state" almost on the lines of current boundaries of Pakistan, Allama Iqbal in the next sentence of the same speech had said, "the state contemplated by the proposal would be much smaller than some of the present Indian provinces. The exclusion of Ambala division, and perhaps of some districts where non-Muslims predominate, will make it less extensive 
and more Muslim in population" (Shamloo, 1948, p.12). Hence, Allama Iqbal in his Allahabad address was demanding the creation of a consolidated Muslim majority state (province) in North-West India with maximum provincial autonomy. Interestingly Allama Iqbal failed to mention the Muslim majority province Bengal in his scheme for Muslims of India.

From the above discussion it becomes clear that the Muslim leadership by the early 1930s was unified on this that federalism on consensus model as enshrined in Jinnah's fourteen points was the only solution for protection of the Muslim rights in united India. Therefore, they completely rejected the federal structure provided under the Government of India Act 1935 which provided for the strong centre and weak provinces. Muslim leadership saw strong centre meant "an increase in Hindu strength" and they opposed the central interference in criminal administration of the provinces under 1935 act because they thought Congress could use it to "paralyse the administration of a Muslim province" (Aziz, 1967, p.47).

This did happen under Congress ministries 1937-39 which convinced many Muslim leaders in Muslim majority provinces to join the Muslim League bandwagon to compete with Congress and preserve their provincial autonomy. The Congress ministries helped Muslim League to enter the Muslim majority provinces as Muslim League then stood for federalism and the maximum provincial autonomy which received traction in Bengal, Sindh and Punjab. In 1940 Lahore resolution reference to "Independent states in which the constituent units shall be autonomous and sovereign" clearly meant it was demanded that the Muslim majority provinces of North-Western and Eastern zones of India must enjoy the maximum autonomy in their internal affairs (Waheed-uz-Zaman, 1978, p.196).

Hence, the careful reading of the Pakistan movement from 1929 to 1940 tells us Federalism and provincial autonomy had been the focal point of Muslim discourse in British India. But Gandhi and the Congress leadership completely failed to understand the concerns of Muslim leadership and were unwilling to address them until it was too late. Congress only saw all this as a British conspiracy to divide and rule, paying no heed to the genuine concerns and fears of Muslims about majoritarian democracy under overwhelmingly Hindu dominated Congress rule. It was too little too late when Gandhi had invited Quaid-i-Azam Mohammad Ali Jinnah in September 1944 to discuss the concerns of Muslims. By then Jinnah and Muslims were already convinced that they had no future in united India and that Pakistan was the only way the Muslims of India could live with peace and freedom. Nevertheless, Quaid-i-Azam had accepted the Cabinet Mission proposals which provided for a weak centre with foreign affairs, defence and communications only and leaving all the residuary powers for provinces in 1946. But the new President of Congress, Jawaharlal Nehru rejected the Cabinet Mission proposals and thus the last opportunity of keeping India united was lost.

\section{CONCLUSION}

This study clearly shows from 1924 onwards federalism had remained on top of the agenda of the Muslim League. Initially separate electorates and weightage were considered as sufficient safeguards against the fear of majoritarian model and Hindu raj but by late 1920s Muslims realised only federalism with maximum provincial autonomy could have secured Muslim interests in the united India. On the other hand, Congress wanted the Westminster style majoritarian model to implement their policies in all parts of India. Congress failed to see genuine Muslim concerns and rubbished them as part of the British divide and rule conspiracy. Hence, the failure of Congress to answer the federal question in united India ultimately resulted in the partition of India in 1947.

\section{REFERENCES:}

Ahmed, Sayed Jaffar (2015) 'Intergovernmental Relations in the Federal System', in: Asma Faiz (ed.) Making Federation Work: Federalism in Pakistan After the $18^{\text {th }}$ Amendment, Karachi: Oxford University Press.

Ali, Chaudhry Mohammad (1967). The Emergence of Pakistan. New York: Columbia University Press.

Asif, Manan Ahmed (2020) The Loss of Hindustan: The Invention of India. Harvard: Harvard University Press.

Azad, Maulana Abul Kalam (1959). India Wins Freedom. Calcutta Orient Longmans. 
Aziz, K.K. (1967). The Making of Pakistan: A Study in Nationalism. London: Chatto and Windus LTD.

Bolitho, Hector (1954). Jinnah: Creator of Pakistan. London: John Murray.

Campbell-Johnson, Allen (1952). Mission with Mountbatten. London: Robert Hale.

Coupland, R. (1944). The Indian Problem: Report on the Constitutional problem in India. New York: Oxford University Press.

Elazar, Daniel J. (1985) 'Federalism and Consociational Regimes', Publius: The Journal of Federalism, Volume 15, Issue 2, Pages 17-34.

Gandhi, M.K. (1949). Communal Unity. Ahmedabad: Navajivan Publishing House.

Gopal, Ram (1959). Indian Muslims: A Political History (1848-1947). Bombay: Asia Publishing House.

Gwayer, Maurice and Appadorai A. (1957). Speeches and Documents on the Indian Constitution 1921-1947, London: Oxford University Press

Ikram, S.M. (1965). Modern Muslim India and the Birth of Pakistan, 1858-1951. Princeton, N.J.: Princeton University Press.

Khaliquzzaman, Chaudhury (1961). Pathway to Pakistan. Lahore: Longmans.

Lijphart, Arend (2012). Patterns of Democracy. Government Forms and Performance in Thirty-Six Countries $2^{\text {nd }}$ Edition, Yale: Yale University Press.

Malik, Hafeez (1963). Moslem Nationalism in India and Pakistan. Washington: Public Affairs Press.

Menon, V.P. (1957). The Transfer of Power in India. Calcutta: Orient Longmans.

Pandey, B.N. (1979). The Indian Nationalist Movement 1885-1947: Select Documents. London: The McMillan Pres LTD.

Phillips. C.H. (1962). The Evolution of India and Pakistan, 1858-1947: Select Documents, Oxford: Oxford University Press.

Pirzada, Sayed Sharifuddin (1970). Foundations of Pakistan, Vol.1. Karachi: National Publishing House.

Qureshi, Ishtiaq, Hussain (1965). The Struggle for Pakistan. Karachi: University of Karachi Press.

Rawlinson, H.G. (1948). The British Achievements in India. London: William Hodge.

Riker, W.H. (1964). Federalism: Origin, Operation, Significance. Boston: Little, Brown and Company.

Sayeed, K.B. (1968) Pakistan: The Formative Phase. Oxford: Oxford University Press.

Shaikh, Farzana (2012). Community and Consensus in Islam. Muslim Representation in Colonial India, 1860-1947. Delhi: Imprint One.

Shamloo (1948). Speeches and Statements of Iqbal. Lahore: Al-Manar Academy

Sherwani, Latif Ahmed (1977). Speeches, Writings, and Statements of Iqbal, $2^{\text {nd }}$ Edition (Lahore: Iqbal Academy.

Smith, Vincent A. (1958). The Oxford History of India. Oxford: Clarendon Press.

Waheed-uz-Zaman (1964). Towards Pakistan. Lahore: Publishers United.

Waheed-uz-Zaman (1978). Towards Pakistan, The Third Edition. Lahore: Publishers United. 